\title{
Hidden treasures: the Cajal collection in Madrid
}

\author{
The perceptive drawings, paintings, photographs and slides of Spain's neuroanatomy \\ pioneer record a tale of ambition and rivalry, reports Alison Abbott.
}

In 1906, the two Nobel laureates in medicine brought their hostilities to the prize ceremony. Italy's introverted Camillo Golgi used his speech in front of the King of Sweden to launch a vicious attack on Spain's Santiago Ramón y Cajal and his (correct) theory that the brain is composed of billions of individual cells, or neurons. Cajal spoke only of his scientific observations, but his presentation rang a deliberate death knell for Golgi's alternative theory that the brain was composed of a continuous web of interconnected cells.

The Spaniard was fire to the Italian's ice. Outgoing and passionate, Cajal was a latecomer to neuroanatomy. $\mathrm{He}$ may have been a teenage rebel, but he bent to his domineering father's demands to abandon all notions of being an artist, and studied medicine instead. After his training, Cajal joined the military to fight for Spain in the Ten Years War in Cuba, and came back with malaria, which then became complicated by a tuberculosis infection. Not surprisingly, his first scientific ambition after joining the staff of the University of Saragossa, Spain, in 1875 was to understand and treat such infectious diseases. With the money saved from his military service in Cuba, he bought his first microscope.

Spain was well off the beaten scientific path, but Cajal always tried to keep abreast of developments that might be useful to microscopy. In 1887, when he was already 35 years old, he travelled to Madrid to watch a new demonstration of a method of staining individual nerve cells with silver chromate. Known as the black reaction, it had been developed in 1873 by Golgi. One look down the microscope and Cajal was hooked. "All was sharp as a sketch with Chinese ink," he later wrote in his autobiography.

Cajal dedicated the rest of his life to neuroanatomy. Gone was the sociable and outgoing man: no more casino visits, no more socialclub outings, no more time-wasting with his expanding family. He stopped playing with colour photography and even gave up painting, his first passion.

In Europe, the race was on to crack the brain's neuroanatomy, and Cajal wanted to win it. He improved the resolution of the Golgi method, and over the next 30 years he prepared and stained thousands of brains from various species in different stages of development. $\mathrm{He}$ acquired the best Zeiss microscope available and, drawing on his artistic talent, precisely transferred what he saw onto paper. Often he would make a composite drawing of several micrographs to present a clearer, very persuasive, scientific picture.

Following the stained cells from their bulbous bodies up through their long axons and dendrites, Cajal described the
In 1889 , terrified that his scientific discoveries would be overlooked, Cajal packed up his prodigious collection of slides and drawings along with his precious microscope and embarked on a two-month tour of European scientific centres. The tour culminated in his attendance at the third meeting of the German Anatomical Society in Berlin. His work spoke for itself - which was just as well, given his weak grasp of foreign languages - and won over most sceptics to the individual neuron theory. Except Golgi. The intimidating Italian made sure he was out of town when Cajal passed through Pavia to visit him.

Cajal published more than 100 scientific papers. He also penned popular books and articles and 'howto' manuals, including one that guided young scientists in the art of finding a wife. A potential wife should be wealthy, he advised, but not extravagant, and a good housekeeper who would shield a budding researcher from distracting domestic crises.

Some members of Cajal's family have never accepted that he left his entire scientific and artistic legacy to the institute in Madrid that he founded in 1902 (now the Cajal Institute, belonging to CSIC, the Spanish research council). This reaction has stymied all attempts to create an independent museum for his collection. His 3,700 slides, nearly 2,000 exquisite scientific drawings, his paintings and photographs, equipment and other memorabilia are still stored at the Cajal Institute. Last year, the Spanish government agreed to recognize the collection as being of national interest. Full cataloguing has just been completed, and a museum site should finally be chosen this year.

In the meantime, the collection can be viewed by appointment. While appreciating the clarity of the obviously independent neurons in Cajal's drawings, scientists should heed a warning from the story of Golgi's failure to see what Cajal saw though the microscope, using the very stain that he developed. Golgi was a scientific giant in his own right, but he blindly suspended reasonable judgement when it came to the work of his rival. Alison Abbott is Nature's Senior European Correspondent.

The Cajal collection is at the Cajal Institute, 37 Avenida del Doctor Arce, 28002 Madrid, Spain (http://tinyurl.com/3dk76e). 